\title{
worldview
}

A JOURNAL OF RELIGION AND INTERNATIONAL AFFAIRS

\section{THE DARKENING CLOUDS OF AFRICA}

At a time when our national elections are turning our attention inward to our own domestic problems and outward to the seemingly intractable problems of foreign policy-Vietnam, for example -it may seem quixotic to call attention to South Africa and term it a potential threat to world peace. Yet that is exactly what South Africa is, and we are going to have our attention turned increasingly toward the maze of problems it presents.

As the forceful exchange of opinion concerning Africa in this issue of worldoiew makes evident, the problem focuses on the relation between the black man and the white, the control which the white minority imposes upon the much greater black majority. Most simply stated, the 3.5 milHon whites have been in South Africa for generations, claim it as their homeland, and have no intention of leaving. Furthermore, they are on the whole deeply opposed to the idea of living on a basis of equality with the blacks, who outnumber them by almost 3 to 1 . They have a stanch, unyielding leader in Dr. Hendrik Verwoerd, who refuses to move, practically or theoretically, from his declared policy of apartheid, or racial segregation.

Pressure on the existing system is now being , exerted, however, not only from within but from without, most noticeably by the burgeoning AfroAsian countries. Throughout Africa there is strong and mounting anger at South Africa's racial policy, with its implied claim to inherent white superiority. There have been calls for wide-scale boycott and even theats of invasion, neither of which seem inmediately likely. The Western countries are being called upon to declare their position and to line up behind various proposals. Unfortunately some of the proposals seem as uninviting as the situation they purport to resolve.

Those who are most critical of the Transkei experiment sometimes posit as the one goal that should be striven for, a single undivided country formed as a non-racial democracy where there is one vote to one man. This, if it were possible to bring about, would not only cut through the
Gordian knot of entangled problems, but it would serve as a guide for the multi-racial communities around the world; it would lessen the possibility of widespread conflicts on the basis of color. Is this desirable outcome even remotely possible?

Despite the pressures being exerted on the white African, it does not. He shows no intention of minimizing his control of the country. And while one may not sympathize with his position one can at least understand some of the causes. It is sometimes given to individuals willingly to relinquish that which they highly value, that which asserts and stands as guarantee of their superiority; it is not so given to large communities.

Are the white Africans open to political instruction, persuasion or pressure? This, too, seems unlikely. They have evolved a tight, sophisticated defense that seems relatively untouched by the charges and accusations leveled against them, Are they then subject to economic sanctions, if these were imposed upon them? Apart from the great difficulty of getting enough countries to agree to such a measure-for South Africa is not without friends and she offers investors a good retum-there are technical problems of encapsulating the country to which no one has given an even remotely adequate answer.

Is there a tegal basis for moving against South Africa? Both the General Assembly and the Security Council of the U.N. condemned the racial policies of South Africa and have recommended the use of economic boycott. And some countries have urged that South Africa be dropped from the U.N. as evidence of displeasure. The World Court at the Hague is now being asked to rule on whether South Africa has defaulted in her international obligations because she has imposed apartheid.

None of these condemnations, recommendations, partial boycotts, or legal judgments will do much to alter the problem to which they are addressed. The facts seem to warrant a dispiriting conclusion: the government of South Africa has 
not shifted from a course which will bring it into ever sharper conflict with communities and nations around the world; no one has yet proposed a solution that has inspired the opposing forces even to join in neutral discussion about the problem; there is less and less time to propose, undertake and pursue such necessary discussions.
The challenge to the South Africans, to other Afro-Asian countries, to countries of Western Europe is great. It may be that it will not, even cannot, be entirely met. But it is the path of in. ternational irresponsibility and extreme danger not to make greater efforts than are yet being made.

\section{In the magazines}

"Catholics should involve themselves in the study of population growth, since the decisions made and the actions taken may have serious implications for them and their society," said William E. Moran, Jr. in announcing the theme of the annual conference of the Catholic Association for International Peace. The conference, entitled "Population Growth: Threat to Peace?" is to be held in association with Georgetown University at the Sheraton Park Hotel in Washington, D. C., October 22-25.

Mr. Moran, president of the organization and dean of the School of Foreign Service at the University, commented further that "there is a growing insistence in the United States and elsewhere that the rate of population growth is outrinning man's resources. There is considerable feeling that efforts to improve the lot of man in less developed countries are doomed to failure because of the rate of population growth. The United States and the international community propose to do something about this problem... This demands a better understanding by Catholics of the issues and of the kind of public policy which is morally acceptable."

It is the aim of the 37th annual CAIP conference, which will attract participants from all over the world, "to take a first step in providing this kind of information and guidance," Dean Moran stated.

$\checkmark$

A paper prepared by a Poliny Committee of the General Board of Christian Soual Concerns of The Methodist Church and reprinted in their bi-monthly publication, Concern (July 15), addresses itself to the responsibility of the Christian citizen and his church toward a fast growing world population.

The document asserts at the outset that such a responsibility does exist: It is yet another aspect of that "stewardship and planning" which; like "God's action in nature" and "in human living", aid in the growth and regulation of the environment and of human life.
According to the board committee the important question for Christians is, this: "Will man decide voluntarily to promote stewardship in birth-making, to compensate for the advantages sought through life saving? Or will man unkrowingly promote deathmaking through starvation, epidemies, or war" and risk the "totalitarian reorganization of world production and distribution"?

The paper suggests that assistance programs of fanily planing and birth control go hand in hand with those foreign aid and foreign policy measures which seek, in some manner, to manage, expand and control the economic and social development of those people in the less wealthy areas of the world. Responsibility for the delay in meeting the problems of "nations that are confronted with the need of large scale technical assistance and materials for promotion of family plaining" is laid to "resistance and lack of understanding among religious people in the United States."

As for "the Christian churches," which in the past "led in extending educational and health services to the people of the world," they "are now confronted with another need.... This is the need for helping people understand how they can plan for the chil. dren they want, and how their stewardship of God's resources is affected by population growth, as well as by production, distribution, and conservation of goods and services." To do so, the paper continues, would "be a practical fulfillment of the biblical calling for feeding those who are hungry, healing those who are sick, meeting the needs of even the least, and loving our neighbor as ourself."

\section{$\bullet$}

Almost 2,000-articles and books published in 1963 in the fields of international relations were selected for listing, under sixteen categories, in the May 1964 issue of Background, journal of the International Studies Association.

Material for this second annual listing is of wider

2 worldview 